\title{
Marine Bacteria Associated with the Green Seaweed Ulva sp. for the Production of Polyhydroxyalkanoates
}

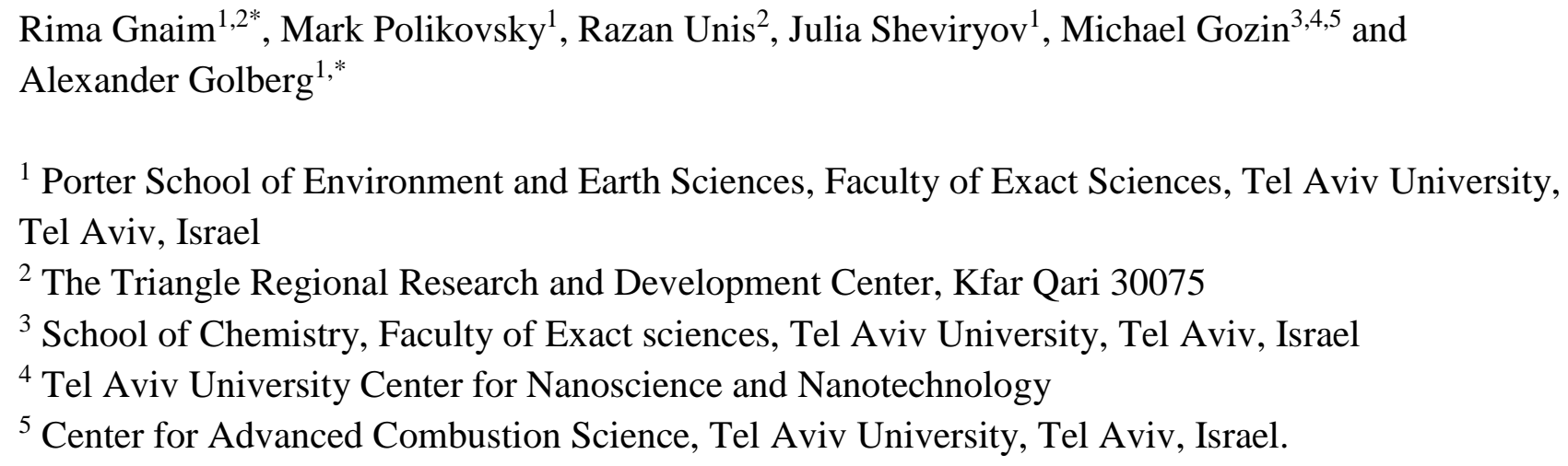

\section{Abstract}

The biosynthesis of polyhydroxyalkanoate (PHA) biopolymers from certain marine microbes, associated with green macroalgae Ulva sp., has attracted significant attention. The Ulva sp. is abundant biomass in numerous locations around the world and could be easily cultivated by marine farming. The variety of sugars found in Ulva sp. homogenate could be used as a carbon source for microbial growth and PHA production. In this work, we isolated and explored a series of bacterial strains that function as potential producers of $\mathrm{P}(3 \mathrm{HB})$, utilizing a range of common sugars found in Ulva sp. Analysis of $16 \mathrm{~S}$ rDNA gene-sequence revealed that the PHA-producing bacteria were phylogenetically related to species of the genus Cobetia, Bacillus, Pseudoaltermonas, and Sulfitobacter. The highest-yield of $\mathrm{P}(3 \mathrm{HB})$ was observed in the case of new Cobetia strain, C. amphilecti, with up to $61 \%(\mathrm{w} / \mathrm{w})$ in the presence of mannitol and $12 \%(\mathrm{w} / \mathrm{w})$ on Ulva sp. acid hydrolysate as a substrate.

\section{Keywords}

Polyhydroxyalkanoate (PHA), Polyhydroxybuterate (P3HB), Marine Bacteria, Fermentation, Green Macro-algae, Ulva sp. hydrolysate 


\section{Introduction}

Limited petroleum resources and their significant environmental impacts have led to an increase in biopolymers development from renewable resources ( $\mathrm{Li}$ et al., 2016). Among these polymers are polyhydroxyalkanoats.

Polyhydroxyalkanoates (PHAs) are prospective substitutes for petrochemical-derived polymers due to their biodegradability, sustainability, and versatile thermal and mechanical properties (Grigore et al., 2019; Muhammadi et al., 2015). PHAs are intracellular microbial aliphatic polyesters, which are synthesized by numerous organisms as carbon and energy storage in intercellular granules (Grigore et al., 2019). The PHAs are usually produced as a response to environmental stresses such as nutrient limitation (Kasan et al., 2015).

To date, around 150 various chemical structures of PHA were reported (Sagong et al., 2018). Poly- $\beta$-hydroxybutyrate $(\mathrm{P}(3 \mathrm{HB}))$ gained more recognition due to its unique physio-mechanical properties. Thus, it offers great potential for use in various industrial applications in agriculture, food packaging and bio-medical fields (Mostafa et al., 2020a). The development of desirable PHA polymers from a widespread microbial resource for industrial purposes are being investigated (Kourmentza et al., 2017). Recently, marine microbial strains such as Alteromonas, Bacillus, Pseudomonas spp., Cupriavidus spp. (Możejko-Ciesielska and Kiewisz, 2016) have gained a lot of attention, they can produce superior PHA polymers because of the stressed marine conditions they live in (Mostafa et al., 2020b).

Although many bacterial species have been identified to produce PHA, the potential to discover and identify novel marine species isolated from green macroalgae with vastly superior production capacity remains untapped. Besides, optimization of bacteria growth and PHA accumulation using various carbon sources presents an essential component for the commercialization of these biopolymers (Sangkharak and Prasertsan, 2012).

Marine macroalgae or seaweeds, especially Ulva sp. are one of the most attractive biomass for exploring PHA production by their associated bacteria due to macroalgae abundance in many ecosystems on earth (Wei et al., 2013). This type of seaweeds offers a lot of environmental and biotechnological benefits comparing to terrestrial crops. For example, they are easily accumulated in many areas around the world; they don't require harsh agronomical treatments, they have high growth rates and high polysaccharide content (Robic et al., 2009) making them a stellar for large-scale production (Gajaria et al., 2017; Jones and Mayfield, 2012).

Numerous studies have described the biosynthesis of a wide range of valuable materials such as biogas, butanol, and ethanol by fermentation of seaweed (Ashokkumar et al., 2017; Leaves and Based, 2019; Scientific et al., 1983; Wise et al., 1979). However, recently seaweed has been explored 
as a potential substrate for PHA production. Studies have shown that bacteria accumulated PHA in a medium containing brown algae (Azizi et al., 2017; Moriya et al., 2020; Muhammad et al., 2020), red algae (Alkotaini et al., 2016; Bera et al., 2015; Sawant et al., 2018), and green seaweed Ulva sp. (Ghosh et al., 2019). Our research group has demonstrated that the Ulva sp. hydrolysate is a promising feedstock for PHA production using Haloferax mediterranei (Ghosh et al., 2019).

In the present study, more than one hundred strains of bacteria isolated from green macroalgae Ulva sp. were evaluated for their capability to manufacture PHAs with various supplemented fermentative substrates found to be in macroalgae, e.g., glucose, fructose, galactose, mannitol, mannose, arabinose, rhamnose, glucuronic acid, and xylose. A total of thirty-one bacteria found to produce PHA. Ten strains related to genus Cobetia, Bacillus, Pseudoaltermonas, and Sulfito-bacter, which showed high PHA yields among the isolates, were further investigated. The effect of the type of supplemented sugars on the growth and PHA productivity of the strains was studied. Furthermore, the effect of bacteria co-culture and mixed substrates on the production of PHA was investigated. Also, 16S rRNA sequence identification of several isolated bacteria was performed. Finally, the ability of the strain Cobetia 105 to produce PHA on Ulva sp. acid hydrolysate, was demonstrated. This study could contribute to the understanding of the diversity of bacteria, associated with marine macroalgae, in terms of PHA productivity and bacteria strains.

\section{Materials and Methods}

\section{Chemicals, instruments and media}

For bacterial cultivation on plates, Agar powder (2\% w/v) (Difco, USA) was dissolved in a medium with Marine Broth (Beit Dekel, Israel) containing (per L) $19.4 \mathrm{~g} \mathrm{NaCl}, 3.24 \mathrm{~g} \mathrm{MgSO}_{4} \cdot 7 \mathrm{H}_{2} \mathrm{O}, 5.0 \mathrm{~g}$ Peptone, $8.8 \mathrm{~g} \mathrm{MgCl}_{2} \cdot 6 \mathrm{H}_{2} \mathrm{O}, 1.8 \mathrm{~g} \mathrm{CaCl}_{2}, 1$ g yeast extract, $0.55 \mathrm{~g} \mathrm{KCl}$ and $0.16 \mathrm{~g} \mathrm{NaHCO}_{3}(\mathrm{pH}$ 7.6). The supplemented sugars (glucose, fructose, galactose, mannitol, mannose, arabinose, rhamnose, glucuronic acid, and xylose) were purchased from Sigma-Aldrich (Israel). Nile Blue (Sigma-Aldrich, Israel) for staining of PHA was used for the screening of isolated bacteria. The sugar's solutions were filtered through a $0.22 \mu \mathrm{m}$ pore membrane microfilter (CSI, Israel). Bateria in liquid cultures was grown in aerobic flask bottles $(175 \mathrm{~mL})$ in a shaking incubator.

\section{Growth of the green macroalga Ulva sp}

The growth of Ulva sp. was carried out by adding 20 gram of fresh Ulva sp. in $40 \mathrm{~mL}$ cylindrical, sleeve-like seaweed photobioreactor (MPBR, Polytiv, Israel) (Chemodanov et al., 2017) in a seawater medium containing 3.7\% w/v of dried Red Sea salt (Red Sea Inc, IS), ammonium nitrate $\left(\mathrm{NH}_{4} \mathrm{NO}_{3}\right.$, Haifa Chemicals Ltd, Israel) and phosphoric acid $\left(\mathrm{H}_{3} \mathrm{PO}_{4}\right.$, Haifa Chemicals Ltd, Israel). The final concentration of nitrogen $\left(\mathrm{N}_{2}\right)$ and phosphorus $(\mathrm{P})$ in the medium were $6.4 \mathrm{~g} \mathrm{~m}^{-3}$ and $0.97 \mathrm{~g} \mathrm{~m}^{-3}$, 
respectively. The $\mathrm{pH}$, temperature and flow rate were controlled as stated in our earlier work (Chemodanov et al., 2017).

\section{Acid hydrolysis of the green macroalga Ulva sp}

Ulva sp. was dried at a temperature of $40^{\circ} \mathrm{C}$ after harvesting. Subsequently, the dried biomass was crushed with an electric grinder (Grinding machine, Henan Gelgoog Machinery GG9FZ-19) to obtain fine powdered Ulva sp. The acid hydrolysis was performed as described in our previous study (Id et al., 2020). Briefly, 45 grams of dry powdered Ulva sp. were added to $500 \mathrm{~mL}$ of sulfuric acid solution $(2 \% \mathrm{v} / \mathrm{v})$. The sample was autoclaved at $121^{\circ} \mathrm{C}$ for 30 minutes. The solution was cooled, and the $\mathrm{pH}$ was adjusted to 6.7 by adding $117 \mathrm{~mL}$ of $3 \mathrm{M} \mathrm{NaOH}$ solution and $80.6 \mathrm{~mL}$ of PBS buffer (Phosphate Buffer Saline). Subsequently, $12.2 \mathrm{~mL}$ of Marine Broth was added to the medium to supplement minerals and nitrogen sources, and the solution was filtered with $0.22 \mu \mathrm{m}$ syringe-filter (Millipore, USA).

\section{Analysis of Ulva sp. acid hydrolysate by Ion chromatography}

The chemical composition of the Ulva sp. acid hydrolysate products was determined using highpressure ion chromatography (HPIC) via Dionex ICS-5000 (Dionex, Thermo Fischer Scientific, MA, USA). The acid hydrolysate solution was diluted in ultrapure water to reach a ratio of 1:2. The sample was then filtered with a $0.22 \mu \mathrm{m}$ syringe filter (Millipore, USA) and added to HPIC vials (Thermo Fischer Scientific, USA). The phase flow rate was $0.25 \mathrm{~mL} / \mathrm{min}$, and the column temperature was set to $30^{\circ} \mathrm{C}$. The standards used as a reference to identify and quantify the resulted monosaccharides were fructose, xylose, glucose, galactose, rhamnose and Glucuronic acid (Sigma-Aldrich, Saint-Louis, USA).

\section{Isolation of bacterial strains}

Ulva sp., a green seaweed collected from the Mediterranean Sea, was used as a source of PHAproducing bacteria. The isolation of bacteria was carried out by three to six isolation rounds, up to achieving a homogenous single colony, which was detected by binocular (Figure 1). The first isolation round was done by smearing live algae thalli after it was harvested in the Israeli eastern part of the Mediterranean Sea or by smearing seawater. The first bacterial isolation round was done on plates with five different carbon sources with three different concentrations of the agar 0.7, 1 and $1.5 \%$ agar. The five media contents were: (1) natural Mediterranean seawater (SW); (2) live Ulva sp. (5 g wet weight) with double-distilled water (DDW); (3) Ulva sp. dried at $40^{\circ} \mathrm{C}$ and was ground with mortar and pestle, for the medium preparation was taken $1.5 \%$ of Ulva sp. dry weight (DW) with 
DDW; (4) marine broth (MB) (Marine Broth 2216, BD Difco), $3.7 \mathrm{~g} \mathrm{~L}^{-1}$ in DDW; (5) DDW without any carbon source. All media were autoclaved and poured into Petri dishes. The subsequent isolation rounds were done by streak-plating bacteria cultures up to isolate a single colony. All isolation rounds after the first round were done on MB plates (1.5\% agar). Finally, 110 isolated bacteria colonies were transferred to $2 \mathrm{~mL}$ liquid marine broth $\left(3.7 \mathrm{~g} \cdot \mathrm{L}^{-1}\right)$ and kept for overnight at $32^{\circ} \mathrm{C}$ in a shaker incubator (180 RPM, Incu-Shaker Mini, Benchmark Scientific). The bacteria were stored in glycerol (final concentration of $25 \%$ ) at $-80^{\circ} \mathrm{C}$.

\section{Screening of bacteria utilizing different sugars for PHA production}

All of 110 bacterial isolates were tested for PHA production using Nile Blue A staining method. The bacteria isolates were cultivated on agar plates containing $\mathrm{MB}$ and the selected sugar $(2 \% \mathrm{w} / \mathrm{v})$ and incubated for four days at $32^{\circ} \mathrm{C}$. Nile Blue A $(0.5 \mu \mathrm{g} / \mathrm{mL})$ was directly added to a rich Marine Broth agar medium; thus, the bacterial cells were grown in the presence of the dye. Subsequently, the bacteria were exposed to UV illumination $(320 \mathrm{~nm})$ using the ENDURO ${ }^{\mathrm{TM}}$ GDS Gel Documentation System (Labnet International, Inc. Israel). This technique allowed rapid screening of the viable colonies for PHA production and considered to be a powerful tool for distinguishing between PHAnegative and PHA-positive strains. The bacteria that have shown a bright white fluorescence on irradiation with UV light were selected as potential PHA accumulators. The selected bacteria were repeatedly grown on different sugars in Marine Broth plates, and the accumulation of PHA on each sugar was also examined by Nile Blue staining. All experiments were carried out in triplicates.

\section{Molecular identification of the isolates}

PHA-positive bacteria were genomically identified to the genus level using $16 \mathrm{~S}$ sequencing profiling. For strain identification, genomic DNA extraction was performed, a colony of each bacterial strain was transferred into a $2 \mathrm{~mL}$ sterile tube containing distilled water. The samples were then centrifuged for 3 minutes at $10000 \mathrm{RPM}$ and heated for 10 minutes at $100^{\circ} \mathrm{C}$ in an Eppendorf Thermomixer $\mathrm{C}$ (Thermo Fisher Scientific, USA) to lyse the bacterial cells. The supernatant of the sample, which contains the DNA fragments, was obtained, and the cell pellet was discarded. The microbial DNA was purified using the Exo-sap DNA Clean-Up Kit (Sigma- Aldrich, Israel) using $5 \mathrm{~L}$ aliquot of the supernatant. The 16S rDNA was amplified by PCR using standard protocols (Wang et al., 2011) based on the primers data shown in Table 1. The PCR product was purified by Exo-sap clean up kit. Sequencing of $16 \mathrm{~S}$ rDNA was carried out by TAU genomic unit, and a homology search of the databases was performed using the BLAST. A phylogenetic tree was constructed using the neighborjoining DNA distance algorithm (Saitou and Nei, 1987) using Mega 5. The resultant tree topologies were evaluated by bootstrap analysis of neighbor-joining data sets based on 100 resamplings. 


\section{Cultivating of PHA-producing isolates in liquid media with different sugars}

Starters of the selected PHA-positive bacteria were prepared by adding one bacterial colony into Marine Broth (MB) medium and were incubated for 18 hours at $37^{\circ} \mathrm{C}$. The bacteria starters were poured into a single sterile bottle. $1.75 \%$ of $\mathrm{MB}$ media $(900 \mathrm{~mL})$ was prepared and autoclaved. The selected carbon source $(2 \% \mathrm{w} / \mathrm{v})$ was dissolved in the medium and adjusted to afford $\mathrm{pH} 7$. For each treatment, a sterile glass bottle containing $135 \mathrm{~mL}$ of MB media was prepared. Subsequently, $15 \mathrm{~mL}$ of bacteria were added from the bacteria inoculum to the medium (total volume of $150 \mathrm{~mL}$ ). The content of the bottles was then appropriately mixed, and the $150 \mathrm{~mL}$ solutions were divided to afford three portions of $50 \mathrm{~mL}$ solutions. The cultures were grown under aerobic conditions in a shaking incubator at $32^{\circ} \mathrm{C}$ with a rotational speed of $90 \mathrm{rpm}$ for four days. The bacterial growth was examined by measuring OD 600. The resulting biomass was collected by centrifugation at $4500 \mathrm{~g}$ for $30 \mathrm{~min}$ in a swing rotor centrifuge (Rotanta 420R, Hettich Instruments LP, USA), rinsed twice with a saline solution followed by 15 min centrifugation, dried in an oven at $45^{\circ} \mathrm{C}$ for $24 \mathrm{~h}$ until a constant weight was obtained. The DW biomass and \%DW per fermentation volume was calculated. PHAs were extracted and analyzed by GC-MS and ${ }^{1} \mathrm{H}-\mathrm{NMR}$. All experiments were carried out in triplicates.

\section{PHA production by bacterial combinations on sugar mixtures}

The best PHA-producing bacteria were chosen to study the effect of bacteria combination and sugar mixture on PHA production. Starters of the selected PHA-positive bacteria were prepared by adding one bacterial colony into Marine Broth (MB) medium and were incubated for 18 hours at $37^{\circ} \mathrm{C}$ following the previously mentioned procedure. The bacteria starters were poured equally $(5 \mathrm{~mL}$ each bacteria) into a sterile bottle. MB media was prepared and autoclaved. The selected carbon source was added to the media ( $2 \% \mathrm{w} / \mathrm{v}$ for each sugar type) and adjusted to afford $\mathrm{pH} 7$. For each treatment, a sterile glass bottle containing $135 \mathrm{~mL}$ of MB media was prepared. Subsequently, $15 \mathrm{~mL}$ of bacteria were added from the bacteria inoculum to the media to yield $150 \mathrm{~mL}$ of solution. The bottles were mixed properly, and the $150 \mathrm{~mL}$ solutions were divided equally into three $50 \mathrm{~mL}$ solutions. The cultures were grown under aerobic conditions in a shaker (90 rpm) at $32^{\circ} \mathrm{C}$ for 4 days. The bacterial growth was examined by measuring OD 600. The resulting biomass was collected by centrifugation at $4500 \mathrm{~g}$ for $30 \mathrm{~min}$ in a swing rotor centrifuge (Rotanta 420R, Hettich Instruments LP, USA), rinsed twice with a saline solution followed by 15 min centrifugation, dried in an oven at $45^{\circ} \mathrm{C}$ for $24 \mathrm{~h}$ until a constant weight was obtained. The DW biomass and \%DW per fermentation volume was calculated. PHAs were extracted and analyzed using GC-MS and ${ }^{1} \mathrm{H}-\mathrm{NMR}$. All experiments were carried out in triplicates. 


\section{PHA production by Cobetia 105 on Ulva sp. acid hydrolysate}

Starters of Cobetia isolate no. 105 were prepared by adding one bacterial colony into Marine Broth (MB) medium and were incubated for 18 hours at $37^{\circ} \mathrm{C}$ following the procedure mentioned above. The bacteria starters were poured into a single sterile bottle. The selected carbon source was added to the Ulva sp. hydrolysate media $(2 \% \mathrm{w} / \mathrm{v})$. A sterile glass bottle containing $135 \mathrm{~mL}$ of hydrolysate media was prepared. Subsequently, $15 \mathrm{~mL}$ of bacteria were added from the bacteria inoculum to the media to yield $150 \mathrm{~mL}$ of solution. The bottles were then mixed properly, and the $150 \mathrm{~mL}$ solutions were divided equally into three $50 \mathrm{~mL}$ solutions. The cultures were grown under aerobic conditions in a shaker $(90 \mathrm{rpm})$ at $32^{\circ} \mathrm{C}$ for 4 days. The bacterial growth was examined by measuring OD 600 . The resulting biomass was collected by centrifugation at $4500 \mathrm{~g}$ for $30 \mathrm{~min}$ in a swing rotor centrifuge (Rotanta 420R, Hettich Instruments LP, USA), rinsed twice with a saline solution followed by 15 min centrifugation, dried in an oven at $45^{\circ} \mathrm{C}$ for $24 \mathrm{~h}$ until a constant weight was obtained. The DW biomass and \%DW per fermentation volume was calculated. PHAs were extracted and analyzed using GC-MS and ${ }^{1} \mathrm{H}-\mathrm{NMR}$. All experiments were carried out in triplicates.

\section{Characterization and quantification of PHA by GC-MS}

PHAs were analyzed after direct acid-catalyzed trans-esterification with methanol of the dried bacteria (DB). The tested samples of DB $(10-30 \mathrm{mg})$ were added to a mixture of chloroform (1.0 $\mathrm{mL})$, benzoic acid $\left(1.0 \mathrm{mg}\right.$, an internal standard, BA), methanol $(2.0 \mathrm{~mL})$ and concentrated $\mathrm{H}_{2} \mathrm{SO}_{4}(0.5$ $\mathrm{mL}$ ). The suspension was heated at $90^{\circ} \mathrm{C}$ with magnetic stirring for overnight in a closed vial. The reaction mixture was cooled to room temperature and treated with a cooled saturated $\mathrm{NaCl}$ solution $(15 \mathrm{~mL})$ and chloroform $(10 \mathrm{~mL})$. Anisole $(1.0 \mathrm{mg}$, an external standard, AN) and 2,4dimethylanisole (1.0 mg, an external standard, DMA) were added to the mixture. The organic phase was washed twice with water, separated, dried over anhydrous sodium sulfate and concentrated under vacuum to obtain $1 \mathrm{~mL}$ solution. GC-MS was used to analyze the PHA methanolysis products and their chemical composition. GC-MS analysis was performed using a Thermo Trace 1310 GC, equipped with a TG-SQC GC capillary column ( $15 \mathrm{~m}, 0.25 \mathrm{~mm}$ i.d., $0.25 \mu \mathrm{m}$ film thickness) and a mass spectrometer ISQ LT as the detector. The carrier gas was helium at a flow rate of $1.2 \mathrm{~mL} / \mathrm{min}$. The column temperature was initially $50^{\circ} \mathrm{C}$ for $1 \mathrm{~min}$, then gradually increased to $200^{\circ} \mathrm{C}$ at $10^{\circ} \mathrm{C} / \mathrm{min}$, and finally increased to $285^{\circ} \mathrm{C}$ at $20^{\circ} \mathrm{C} / \mathrm{min}$. For GC-MS detection, an electron ionization system was used with ionization energy of $70 \mathrm{eV}$. The samples were diluted 1:1000 (v/v) with ultra-pure hexane, and $1.0 \mu \mathrm{L}$ of the diluted samples $(8 \mathrm{ng} / 1 \mu \mathrm{L})$ was injected automatically in split mode. Injector and detector temperatures were set at $250^{\circ} \mathrm{C}$. All experiments were carried out in triplicates. 


\section{${ }^{1}$ H NMR analysis}

All samples were dissolved in deuterated $\mathrm{CDCl}_{3}$ prior analysis $(5 \mathrm{mg} / \mathrm{mL})$. Each sample was shaken vigorously till complete dissolution was achieved, and about $0.5 \mathrm{~mL}$ of it was transferred into an NMR tube for analysis and run ${ }^{1} \mathrm{H}-\mathrm{NMR}$ with Pulse Program zg30 on Bruker AVANCE III 500 MHz NMR Spectrometer with 5 mm PABBO-BB probe and Topspin 3.0 software.

\section{Statistical Analysis}

The results were statistically analyzed using Excel and GraphPad prism 8 for data management and quantitative analysis. One-way and two-way ANOVA using Tukey and Holm-Sidak's multiple comparison tests were performed for analyzing standard deviation, means and statistical significance

\section{Results}

\section{PHA accumulation by Ulva sp. associated bacterial strains utilizing different sugars}

A total of 110 bacteria were isolated from Ulva sp. and screened for PHA production by using Nile Blue A staining method. All positive-PHA strains exhibited a white fluorescent emission on agar plates containing different sugars under UV light. For example, Figure 2 shows the diversity of PHA production of Cobetia isolate no. 104 that produces PHA mainly in mannitol, fructose, galactose, and glucose, while no PHA was observed with Cobetia isolate no. 104 in the presence of other sugars. It is important to emphasize that all tested bacteria did not produce PHA when grown on MB alone as a control. Based on fluorescence staining, 28 bacteria were found to accumulate PHA to a different extent in the presence of glucose, fructose, mannitol, and galactose. The sugar substrate with the highest number of bacteria that produce PHA is glucose with 27 different strains, followed by fructose with 24 strains, then mannitol and galactose with 17 strains (Table 2).

\section{PHA-Producing Bacteria Identification Using 16S rRNA Gene and Phylogenetic Analysis}

Molecular identification of the isolates was carried out by the sequencing of 16S rRNA gene. Amplification of bacterial genomic DNA by primers yielded 1400-1500 bp fragments (Figure 3). The bacteria were found to be within the genus of Cobetia, Bacillus, Sulfitobacter and Pseudoaltermonas. The phylogenetic relationship among the Cobetia isolates is provided in Figure 4. Cobetia no. 65, Cobetia no. 92, and Cobetia no. 104 were found to have 16S rRNA similarity and close relation to Cobetia amphilecti. Cobetia no. 105, Cobetia no. 75, Cobetia no. 76. On the other hand, Cobetia no. 107 were found to have a close genomic characterization and likely related to both $C$. pacifica and $C$. litoralis. Besides, Cobetia isolates found to have a strong evolutionary relationship with Halomonas, 
as was suggested by Arahal et al. (Arahal et al., 2002). Most of these bacteria are PHA producers. Bacillus isolate no. 3, also found to have a close genomic relationship to B. cereus, B. mobilis, B. pacificus and B. thuringiensis with $98 \%$ identity. Two or more distinct Bacillus species may possess identical 16S rDNA sequences (Ash et al., 1991; IJsselmuiden and Faden, 1992). Additional taxonomic studies on the isolates showed that isolate no. 48 has a genomic relationship to Sulfitobacter sp. and isolate no. 71 has a genomic relationship to Pseudoaltermonas sp.

\section{Chemical structure and amount of the produced $\mathrm{P}(3 \mathrm{HB})$ by Cobetia, Bacillus, Pseudoaltemonas and Sulfitobacter}

The results of the produced methylated ester derivatives obtained by acid methanolysis of PHA showed mainly two large peaks corresponding to methyl-3-hydroxybutyrate (M3HB, $\mathrm{R}_{t}=3.15 \mathrm{~min}$ ), and methyl-3-methoxy-butanoate (M3MB, $\mathrm{R}_{\mathrm{t}}=3.97 \mathrm{~min}$ ), and a small peak corresponding to levulinic acid (LA, $\mathrm{R}_{t}=5.89 \mathrm{~min}$ ) in addition to our three standards (anisole-ANS $\mathrm{R}_{t}=4.67$ min; methyl benzoate-MB $\mathrm{R}_{\mathrm{t}}=7.03 \mathrm{~min}$ and 2,4-dimethylanisole-DMA $\mathrm{R}_{\mathrm{t}}=7.49 \mathrm{~min}$ ) as shown in a typical GCMS chromatogram in Figure 5. The presence of M3HB and M3MB monomers indicated that the PHA polymer is mainly $\mathrm{P}(3 \mathrm{HB})$.

The dry cell weight (DCW, $\left.\mathrm{g} \mathrm{L}^{-1}\right), \mathrm{P}(3 \mathrm{HB})$ content (\%DCW), and $\mathrm{P}(3 \mathrm{HB})$ yield $\left(\mathrm{mg} \mathrm{L}^{-1}\right)$ values obtained with different Ulva sp. associated bacteria grown on different supplemented sugars are presented in Table 3. Cell growth of $1.14 \mathrm{~g} \mathrm{~L}^{-1}$ and $1.96 \mathrm{~g} \mathrm{~L}^{-1}$, and $\mathrm{P}(3 \mathrm{HB})$ content yield of $10.03 \%$ and $13.97 \%$ were obtained when Bacillus was grown in a medium containing fructose and glucose, respectively. Sulfitobacter produced $7.73 \%$ of $\mathrm{P}(3 \mathrm{HB})$ and $2.54 \mathrm{~g} \mathrm{~L}^{-1}$ of DCW when it was grown in medium containing mannitol. A DCW of $6.63 \mathrm{~g} \mathrm{~L}^{-1}$ and $1.06 \mathrm{~g} \mathrm{~L}^{-1}$ and a $\mathrm{P}(3 \mathrm{HB})$ production of $17.11 \%$ and $11.83 \%$ were obtained with Cobetia isolate no. 65 grown in medium containing mannitol and galactose, respectively. Pseudoaltermonas produced $7.46 \%$ of $\mathrm{P}(3 \mathrm{HB})$ with $\mathrm{DCW}$ of $2.54 \mathrm{~g} \mathrm{~L}^{-1}$ when grown in medium containing fructose, while no PHA was produced on other sugars. The highest DCW of Cobetia isolate no. 75 was obtained when it was grown in a medium containing mannitol or glucose (4.72 $\mathrm{g} \mathrm{L}^{-1}$ and $3.72 \mathrm{~g} \mathrm{~L}^{-1}$, respectively), and the highest $\mathrm{P}(3 \mathrm{HB})$ production was achieved with mannitol (18.56\%) and glucose (20.91\%). Cobetia isolate no. 104 produced the highest amount of $\mathrm{P}(3 \mathrm{HB})$ in fructose $(23.39 \%)$. Cobetia isolate no. 105 produced $61 \%$ of $\mathrm{P}(3 \mathrm{HB})$ in mannitol with $4.58 \mathrm{~g} \mathrm{~L}^{-1}$ of DCW. Cobetia isolate no. 107 produced the highest $\mathrm{P}(3 \mathrm{HB})$ amount when it was grown in fructose (27.45\%) with a DCW of $3.53 \mathrm{~g} \mathrm{~L}^{-1}$. The highest $\mathrm{P}(3 \mathrm{HB})$ amount using Cobetia isolate no. 92 was obtained in mannitol (8.91\%) with $4.5 \mathrm{~g} \mathrm{~L}^{-1}$ of DCW.

Cobetia isolate no. 75, Cobetia isolate no. 92, Cobetia isolate no. 104 and Cobetia isolate no. 107 produce $\mathrm{P}(3 \mathrm{HB})$ mainly on galactose, mannitol, fructose, and glucose. While Cobetia isolate no. 65 produce $\mathrm{P}(3 \mathrm{HB})$ on galactose and mannitol. Cobetia isolate no. 105 produce $\mathrm{P}(3 \mathrm{HB})$ mainly on 
mannitol and fructose, and Cobetia isolate no. 76 produce $\mathrm{P}(3 \mathrm{HB})$ mainly on fructose, glucose, and mannose.

\section{Effect of bacterial combination and sugar mixtures on the PHA production}

Mixed culture systems were shown to produce large amounts of PHAs in a wide range of low-cost substrates (Shalin et al., 2014). We have grown the best PHA-producers on three sugar substrates with a total concentration of $2 \%$ w/v. Cobetia isolate no. 107, Cobetia isolate no. 104, Cobetia isolate no. 92 , Cobetia isolate no. 65 , Cobetia isolate no. 75 were selected to study the effect of bacteria combinations on bacteria growth and PHA production. The selected sugars were glucose, fructose and mannitol. The results in Figure 6 present the biomass amount, PHA amount and yield of all Cobetia strains on a mixed culture of glucose, fructose and mannitol. The highest biomass, PHA amount and PHA yield were obtained by Cobetia isolate no. 105 with $2.03 \mathrm{~g} \cdot \mathrm{L}^{-1}, 712 \mathrm{mg} \cdot \mathrm{L}^{-1}$ and $35.1 \%$ respectively. The results presented in Table 4 show that a mixed culture of different species of bacteria afforded relatively low DCW and P(3HB) yields. For example, Cobetia isolate no. 107 alone and Cobetia isolate no. 104 alone produced $27.45 \% \mathrm{w} / \mathrm{w}$ and $23.29 \% \mathrm{w} / \mathrm{w}$ of $\mathrm{P}(3 \mathrm{HB})$ in fructose, respectively. However, a mixed culture of these two bacteria in fructose afforded only $10.05 \%$ of $\mathrm{P}(3 \mathrm{HB})$. A similar result was observed when a bacterial combination of Cobetia isolate no. 65, isolate no. 75, and isolate no. 105 in mannitol was used. A yield of $11.61 \%$ of $\mathrm{P}(3 \mathrm{HB})$ was obtained for the mixed bacteria compared to $17.11 \%$ for Cobetia isolate no. $65,18.56 \%$ for Cobetia isolate no. 75 , and $61 \%$ for Cobetia isolate no. 105. Notably, additional valuable fine chemicals were also exhibited in a very low amount, such as hexane-2,5-dione and levulinic acid.

\section{PHA production by Cobetia isolate no. 105 on Ulva sp. hydrolysate}

A mixture of monosaccharides was obtained by acid hydrolysis of Ulva sp. which were quantified using HPIC (Table 5). The hydrolysate composed of glucose $(16.1 \pm 0.8 \mathrm{mg} / \mathrm{g} \mathrm{DW})$, rhamnose $(6.2 \pm 0.45 \mathrm{mg} / \mathrm{g} \mathrm{DW})$, fructose $(2.8 \pm 0.41 \mathrm{mg} / \mathrm{g} \mathrm{DW})$, xylose $(1.6 \pm 0.22 \mathrm{mg} / \mathrm{g} \mathrm{DW})$, galactose $(1.0 \pm 0.11 \mathrm{mg} / \mathrm{g}$ DW) and glucuronic acid $(1.3 \pm 0.11 \mathrm{mg} / \mathrm{g} \mathrm{DW})$. PHA production by Cobetia no. 105 on Ulva sp. hydrolysate was investigated (Figure 7). The results showed a biomass concentration of $1.4 \pm 0.12 \mathrm{~g} \cdot \mathrm{L}^{-1}$ and PHA yield (\% DCW) of $12 \%(\mathrm{w} / \mathrm{w})$. The ${ }^{1} \mathrm{H}-\mathrm{NMR}$ spectrums of the PHA extracted from Cobetia isolate no. 105 grown on Ulva hydrolysate in comparison to that grown on sugar mixture are shown in Figure 8 and 9. The ${ }^{1} \mathrm{H}-\mathrm{NMR}$ spectral data matched with the ${ }^{1} \mathrm{H}-\mathrm{NMR}$ spectrum of $\mathrm{P}(3 \mathrm{HBV})$ acquired by (Bloembergen et al., 1989). From the calculated peak integration, it can be concluded that the PHA produced from Cobetia isolate no. 105 grown on sugar mixture (i.e. glucose, fructose and mannitol) contains mainly $3 \mathrm{HB}$ with 0.94 mole $\% 3 \mathrm{HV}$ while $3.29 \mathrm{~mole} \% 3 \mathrm{HV}$ was obtained when Cobetia isolate no. 105 was grown on Ulva sp. acid hydrolysate. 


\section{Discussion}

We have successfully isolated bacteria strains from the green seaweed Ulva sp. that found to accumulate $\mathrm{P}(3 \mathrm{HB})$ on various sugars found in seaweed. Taxonomic studies and 16S rDNA gene sequence analysis revealed that these bacteria are phylogenetically related to species of the genus Cobetia, Bacillus, Sulfitobacter and Pseudoaltermonas. Bacillus isolate no. 3, found to have a close genomic relationship to $B$. cereus, B. mobilis, B. pacificus and B. thuringiensis with $98 \%$ identity. Isolate no. 48 found to have a close relation to Sulfitobacter sp. with $98 \%$ identity. Isolate no. 71 found to have a close relation with Pseudoaltermonas sp. with $98.52 \%$ identity. The closest species of Cobetia are C. amphiletci 46-2 with $100 \%$ identity, C. litoralis KMM 3880 with $99.91 \%$, C. marina and C. pacifica with $99.57 \%$.

The fermentation process was carried out using different bacteria isolates and different sugars for PHA production. Among all the isolates, the highest production of PHA was obtained by Cobetia isolate no. 105 on mannitol with $61 \%$ of $\mathrm{P}(3 \mathrm{HB})$, Cobetia isolate no. 107 on fructose with $27.5 \%$, Cobetia isolate no. 104 on fructose with $23.3 \%$, Cobetia isolate no. 75 on glucose with $20.9 \%$ and Cobetia isolate no. 65 on mannitol with $17.1 \%$.

Cobetia strains found to assimilate various carbon sources, such as fructose, glucose, mannitol and galactose, and produce $\mathrm{P}(3 \mathrm{HB})$ with high productivity. Cobetia was classified originally as Arthrobacter marinus by (Cobet et al., 1971), then Deleya marina by (BAUMANN et al., 1983) and Halomonas marina by (Dobson and Franzmann, 1996). The genus Cobetia contains mainly two wellknown strains, Cobetia marina (Arahal et al., 2002), and Cobetia crustatorum (Kim et al., 2010).

Several studies were conducted on microbial species genetically related to the Halomonas or Cobetia genus as PHA-producers such as Cobetia marina, Halomonas boliviensis LC1, Halomonas elongate DSM 2581, Halomonas salina and Halomonas sp.TD01 (Mothes et al., 2008; Quillaguamán et al., 2005; Tao et al., 2017).

Among all Cobetia strains reported in this study, Cobetia no. 105 which was identified as $C$. amphiletci showed the highest $\mathrm{P}(3 \mathrm{BH})$ yield; $61 \% \mathrm{w} / \mathrm{w}$ when grown on mannitol and $12 \% \mathrm{w} / \mathrm{w}$ on Ulva acid hydrolysate as a sole carbon source. Very recently, Moriya et al. (2020) have reported the production of PHB (13.5\%) by Cobetia strain (5-11-6-3) in a medium containing crushed waste Laminaria sp., (brown seaweed). Furthermore, they have used alginate as a substrate for Cobetia strain 5-11-6-3 which yielded 62.1\% of PHB with a content of $3.11 \mathrm{~g} \mathrm{~L}^{-1}$.

Wang et al. (2010) have evaluated the content of P(3HB) by Pseudoaltermonas sp. SM9913 when was grown on glucose, decanoate and olive oil. The strain revealed $\mathrm{P}(3 \mathrm{HB})$ accumulation of 3.10, $1.89,2.57 \%$ of the cell dry weight when glucose, decanoate and olive oil were provided as a carbon source, respectively (Wang et al., 2010). In our hands, $\mathrm{P}(3 \mathrm{HB}$ ) production up to $7.46 \%$ (w/w) was obtained by Pseudoaltermonas isolate no. 71 on fructose. Mereuta et al. reported for the first time the 
production of $\mathrm{P}(3 \mathrm{HB})$ by Sulfitobacter genus, which was isolated from the black sea (Mereuta et al., 2018).

The $\mathrm{P}(3 \mathrm{HB})$ productivity reported for mixed cultures were found to be lower than the productivity of pure cultures (Serafim et al., 2008). The maximum cell concentration reported for aerobic dynamic feeding (ADF) operated systems was $6.1 \mathrm{gL}^{-1}$ (Dionisi et al., 2006), which is much lower than those obtained by pure cultures, usually above $80 \mathrm{gL}^{-1}$ (Lee et al., 1999). The reason for this result is the apparent difficulty in reaching high biomass concentrations in the mixed-culture process (Oehmen et al., 2014), probably due to bacterial competition on the carbon source. Many studies have demonstrated the production of $\mathrm{P}(3 \mathrm{HB})$ from various marine bacteria (Mostafa et al., 2020a, 2020b; $\mathrm{Pu}$ et al., 2020). In this study, some bacteria isolates found to produce $\mathrm{P}(3 \mathrm{HBV})$.

\section{Conclusions}

In this study, we succeeded in isolating different bacteria strains, including $\mathrm{P}(3 \mathrm{HB})$ and $\mathrm{P}(3 \mathrm{HBV})-$ producing bacteria associated with seaweed Ulva sp. designated C. amphiletci, Sulfitobacter and Pseudo-altermonas from various sugars. The selection of a suitable substrate is an important factor for improving microbial PHA production yield, composition and properties. Based on our findings, we recommend conducting large-scale assays and evaluating the industrial production of $\mathrm{P}(3 \mathrm{HB})$ using these strains in green seaweed biorefineries.

\section{Conflict of interest}

The authors declare no conflict of interest.

\section{Authors contributions}

A.G. and M.G. conceived the idea of the study. R.G., M.P. and A.G. designed the research experiments. M.P. isolated the bacteria from the seaweed. R.G. performed the experiments and analysed the results. J.S. and M.P. helped with molecular identification. R.U. helped with GC-MS analysis. R.G. and A.G. wrote the manuscript.

\section{Acknowledgement}

R.G. thanks the TRDC-TAU collaborative research grant, the Arianne de Rothchild Women's Doctoral Program Scholarship, and the Lewis and Martin Whitman Scholarship for Arab students for financial support of this work. The authors thank The Aaron Frenkel Air Pollution Initiative at Tel Aviv University for financial support. 


\section{References}

Alkotaini, B., Koo, H., Kim, B.S., 2016. Production of polyhydroxyalkanoates by batch and fedbatch cultivations of Bacillus megaterium from acid-treated red algae 33, 1669-1673. https://doi.org/10.1007/s11814-015-0293-6

Arahal, D.R., Castillo, A.M., Ludwig, W., Schleifer, K.H., Ventosa, A., 2002. Proposal of Cobetia marina gen. nov., comb. nov., within the family Halomonadaceae, to include the species Halomonas marina. Syst. Appl. Microbiol. 25, 207-211. https://doi.org/10.1078/0723-202000113

Ash, C., Farrow, J.A.E., Dorsch, M., Stackebrandt, E., Collins, M.D., 1991. Comparative analysis of Bacillus anthracis, Bacillus cereus, and related species on the basis of reverse transcriptase sequencing of 16 S rRNA. Int. J. Syst. Bacteriol. 41, 343-346. https://doi.org/10.1099/00207713-41-3-343

Ashokkumar, V., Razman, M., Salam, Z., Sivakumar, P., Tung, C., Elumalai, S., Suresh, V., Nasir, F., 2017. Production of liquid biofuels ( biodiesel and bioethanol ) from brown marine macroalgae Padina tetrastromatica. Energy Convers. Manag. 135, 351-361. https://doi.org/10.1016/j.enconman.2016.12.054

Azizi, N., Najafpour, G., Younesi, H., 2017. International Journal of Biological Macromolecules Acid pretreatment and enzymatic saccharification of brown seaweed for polyhydroxybutyrate ( PHB ) production using Cupriavidus necator. Int. J. Biol. Macromol. 101, 1029-1040. https://doi.org/10.1016/j.ijbiomac.2017.03.184

BAUMANN, L., BOWDITCH, R.D., BAUMANN, P., 1983. Description of Deleya gen. nov. Created to Accommodate the Marine Species Alcaligenes aestus, A. pacificus, A. cupidus, A. venustus, and Pseudomonas marina. Int. J. Syst. Bacteriol. 33, 793-802. https://doi.org/10.1099/00207713-33-4-793

Bera, A., Dubey, S., Bhayani, K., Mondal, D., Mishra, S., Ghosh, P.K., 2015. International Journal of Biological Macromolecules Microbial synthesis of polyhydroxyalkanoate using seaweedderived crude levulinic acid as co-nutrient. Int. J. Biol. Macromol. 72, 487-494. https://doi.org/10.1016/j.ijbiomac.2014.08.037

Bloembergen, S., Holden, D.A., Bluhm, T.L., Hamer, G.K., Marchessault, R.H., 1989. Stereoregularity in Synthetic 0-Hydroxybutyrate and 1656-1663. https://doi.org/10.1021/ma00194a027

Chemodanov, A., Robin, A., Golberg, A., 2017. Bioresource Technology Design of marine macroalgae photobioreactor integrated into building to support seagriculture for biorefinery and bioeconomy. Bioresour. Technol. 241, 1084-1093. https://doi.org/10.1016/j.biortech.2017.06.061 
Cobet, A.B., Jones, G.E., Albright, J., Simon, H., Wirsen, C., 1971. The effect of nickel on a marine bacterium: fine structure of Arthrobacter marinus. J. Gen. Microbiol. 66, 185-196. https://doi.org/10.1099/00221287-66-2-185

Dionisi, D., Majone, M., Vallini, G., Di Gregorio, S., Beccari, M., 2006. Effect of the applied organic load rate on biodegradable polymer production by mixed microbial cultures in a sequencing batch reactor. Biotechnol. Bioeng. 93, 76-88. https://doi.org/10.1002/bit.20683

Dobson, S.J., Franzmann, P.D., 1996. Unification of the genera Deleya (Baumann et al. 1983), Halomonas (Vreeland et al. 1980), and Halovibrio (Fendrich 1988) and the species Paracoccus halodenitrificans (Robinson and Gibbons 1952) into a single genus, Halomonas, and placement of the genus Zy. Int. J. Syst. Bacteriol. 46, 550-558. https://doi.org/10.1099/00207713-46-2-550

Gajaria, T.K., Suthar, P., Baghel, R.S., Balar, N.B., Sharnagat, P., Mantri, V.A., Reddy, C.R.K., 2017. Integration of protein extraction with a stream of byproducts from marine macroalgae: A model forms the basis for marine bioeconomy. Bioresour. Technol. 243, 867-873. https://doi.org/10.1016/j.biortech.2017.06.149

Ghosh, S., Gnaim, R., Greiserman, S., Fadeev, L., Gozin, M., Golberg, A., 2019. Macroalgal biomass subcritical hydrolysates for the production of polyhydroxyalkanoate (PHA) by Haloferax mediterranei. Bioresour. Technol. 271, 166-173. https://doi.org/10.1016/j.biortech.2018.09.108

Grigore, M.E., Grigorescu, R.M., Iancu, L., Ion, R.M., Zaharia, C., Andrei, E.R., 2019. Methods of synthesis, properties and biomedical applications of polyhydroxyalkanoates: a review. J. Biomater. Sci. Polym. Ed. 30, 695-712. https://doi.org/10.1080/09205063.2019.1605866 Id, E.V., Gillis, A., Polikovsky, M., Bender, B., Golberg, A., Yakhini, Z., 2020. Distributed flux balance analysis simulations of serial biomass fermentation by two organisms 1-17. https://doi.org/10.1371/journal.pone.0227363

IJsselmuiden, C.B., Faden, R.R., 1992. The New England Journal of Medicine Downloaded from nejm.org on January 31, 2011. For personal use only. No other uses without permission. Copyright (C) 1992 Massachusetts Medical Society. All rights reserved. 326.

Jones, C.S., Mayfield, S.P., 2012. Algae biofuels: Versatility for the future of bioenergy. Curr. Opin. Biotechnol. 23, 346-351. https://doi.org/10.1016/j.copbio.2011.10.013

Kasan, N.A., Said, S.M., Ghazali, N.A., 2015. Beneficial Microorganisms in Agriculture, Aquaculture and Other Areas. https://doi.org/10.1007/978-3-319-23183-9

Kim, M.S., Roh, S.W., Bae, J.W., 2010. Cobetia crustatorum sp. nov., a novel slightly halophilic bacterium isolated from traditional fermented seafood in Korea. Int. J. Syst. Evol. Microbiol. 60, 620-626. https://doi.org/10.1099/ijs.0.008847-0 
Kourmentza, C., Plácido, J., Venetsaneas, N., Burniol-Figols, A., Varrone, C., Gavala, H.N., Reis, M.A.M., 2017. Recent advances and challenges towards sustainable polyhydroxyalkanoate (PHA) production. Bioengineering 4, 1-43. https://doi.org/10.3390/bioengineering4020055

Leaves, N., Based, E., 2019. com Neem Leaves Extract Based Seaweed Bio-degradable Composite Films with Excellent Antimicrobial Activity for Sustainable Packaging Material 14, 700-713. Li, Z., Yang, J., Loh, X.J., 2016. Polyhydroxyalkanoates: Opening doors for a sustainable future. NPG Asia Mater. 8, e265-20. https://doi.org/10.1038/am.2016.48

Mereuta, I., Chiciudean, I., Lascu, I., Avramescu, S.M., Stoica, I., Tanase, A.M., 2018.

Polyhydroxyalkanoate production potential of Black Sea new bacterial isolates. J. Biotechnol. 280, S46-S47. https://doi.org/10.1016/j.jbiotec.2018.06.148

Moriya, H., Takita, Y., Matsumoto, A., Yamahata, Y., Nishimukai, M., Miyazaki, M., Shimoi, H., Kawai, S.J., Yamada, M., 2020. Cobetia sp. Bacteria, Which Are Capable of Utilizing Alginate or Waste Laminaria sp. for Poly(3-Hydroxybutyrate) Synthesis, Isolated From a Marine Environment. Front. Bioeng. Biotechnol. 8. https://doi.org/10.3389/fbioe.2020.00974 Mostafa, Y.S., Alrumman, S.A., Alamri, S.A., Otaif, K.A., Mostafa, M.S., Alfaify, A.M., 2020a. Bioplastic (poly-3-hydroxybutyrate) production by the marine bacterium Pseudodonghicola xiamenensis through date syrup valorization and structural assessment of the biopolymer. Sci. Rep. 10, 1-13. https://doi.org/10.1038/s41598-020-65858-5

Mostafa, Y.S., Alrumman, S.A., Otaif, K.A., Alamri, S.A., Mostafa, M.S., Sahlabji, T., 2020b. Production and characterization of bioplastic by polyhydroxybutyrate accumulating Erythrobacter aquimaris isolated from mangrove rhizosphere. Molecules 25. https://doi.org/10.3390/molecules25010179

Mothes, G., Schubert, T., Harms, H., Maskow, T., 2008. Biotechnological coproduction of compatible solutes and polyhydroxyalkanoates using the Genus Halomonas. Eng. Life Sci. 8, 658-662. https://doi.org/10.1002/elsc.200800097

Możejko-Ciesielska, J., Kiewisz, R., 2016. Bacterial polyhydroxyalkanoates: Still fabulous? Microbiol. Res. 192, 271-282. https://doi.org/10.1016/j.micres.2016.07.010

Muhammad, M., Aloui, H., Khomlaem, C., Hou, C.T., Soo, B., 2020. Biocatalysis and Agricultural Biotechnology Production of polyhydroxyalkanoates and carotenoids through cultivation of different bacterial strains using brown algae hydrolysate as a carbon source. Biocatal. Agric. Biotechnol. 30, 101852. https://doi.org/10.1016/j.bcab.2020.101852

Muhammadi, Shabina, Afzal, M., Hameed, S., 2015. Bacterial polyhydroxyalkanoates-eco-friendly next generation plastic: Production, biocompatibility, biodegradation, physical properties and applications. Green Chem. Lett. Rev. 8, 56-77. https://doi.org/10.1080/17518253.2015.1109715 
Oehmen, A., Pinto, F. V., Silva, V., Albuquerque, M.G.E., Reis, M.A.M., 2014. The impact of pH control on the volumetric productivity of mixed culture PHA production from fermented molasses. Eng. Life Sci. 14, 143-152. https://doi.org/10.1002/elsc.201200220

Pu, N., Hu, P., Shi, L.L., Li, Z.J., 2020. Microbial production of poly(3-hydroxybutyrate) from volatile fatty acids using the marine bacterium Neptunomonas concharum. Bioresour. Technol. Reports 11, 100439. https://doi.org/10.1016/j.biteb.2020.100439

Quillaguamán, J., Hashim, S., Bento, F., Mattiasson, B., Hatti-Kaul, R., 2005. Poly( $\beta$ hydroxybutyrate) production by a moderate halophile, Halomonas boliviensis LC1 using starch hydrolysate as substrate. J. Appl. Microbiol. 99, 151-157. https://doi.org/10.1111/j.1365-2672.2005.02589.x

Robic, A., Sassi, J.F., Dion, P., Lerat, Y., Lahaye, M., 2009. Seasonal variability of physicochemical and rheological properties of ulvan in two ulva species (chlorophyta) from the Brittany coast1. J. Phycol. 45, 962-973. https://doi.org/10.1111/j.1529-8817.2009.00699.x

Sagong, H.Y., Son, H.F., Choi, S.Y., Lee, S.Y., Kim, K.J., 2018. Structural Insights into Polyhydroxyalkanoates Biosynthesis. Trends Biochem. Sci. 43, 790-805. https://doi.org/10.1016/j.tibs.2018.08.005

Saitou, N., Nei, M., 1987. The neighbor-joining method: a new method for reconstructing phylogenetic trees. Mol. Biol. Evol. 4, 406-425. https://doi.org/10.1093/oxfordjournals.molbev.a040454

Sangkharak, K., Prasertsan, P., 2012. Screening and identification of polyhydroxyalkanoates producing bacteria and biochemical characterization of their possible application. J. Gen. Appl. Microbiol. 58, 173-182. https://doi.org/10.2323/jgam.58.173

Sawant, S.S., Salunke, B.K., Kim, B.S., 2018. Consolidated bioprocessing for production of polyhydroxyalkanotes from red algae Gelidium amansii. Int. J. Biol. Macromol. 109, 10121018. https://doi.org/10.1016/j.ijbiomac.2017.11.084

Scientific, E., Company, P., Hansson, G., 1983. Methane production from marine, green macroalgae 8, 185-194.

Shalin, T., Sindhu, R., Binod, P., Soccol, C.R., Pandey, A., 2014. Mixed cultures fermentation for the production of poly- $\beta$ - hydroxybutyrate. Brazilian Arch. Biol. Technol. 57, 644-652. https://doi.org/10.1590/S1516-89132013005000016

Tao, W., Lv, L., Chen, G.Q., 2017. Engineering Halomonas species TD01 for enhanced polyhydroxyalkanoates synthesis via CRISPRi. Microb. Cell Fact. 16, 1-10. https://doi.org/10.1186/s12934-017-0655-3

Wang, Q., Zhang, H., Chen, Q., Chen, X., Zhang, Y., Qi, Q., 2010. A marine bacterium accumulates polyhydroxyalkanoate consisting of mainly 3-hydroxydodecanoate and 3- 
hydroxydecanoate. World J. Microbiol. Biotechnol. 26, 1149-1153. https://doi.org/10.1007/s11274-009-0282-1

Wang, T.Y., Wang, L., Zhang, J.H., Dong, W.H., 2011. A simplified universal genomic DNA extraction protocol suitable for PCR. Genet. Mol. Res. 10, 519-525. https://doi.org/10.4238/vol10-1gmr1055

Wei, N., Quarterman, J., Jin, Y.S., 2013. Marine macroalgae: An untapped resource for producing fuels and chemicals. Trends Biotechnol. 31, 70-77. https://doi.org/10.1016/j.tibtech.2012.10.009

Wise, D.L., Augenstein, D.C., Company, D.R.D., Oceanographic, W.H., 1979. METHANE FERMENTATION OF AQUATIC BIOMASS 4, 217-237. 
bioRxiv preprint doi: https://doi.org/10.1101/2020.12.05.413369; this version posted December 6, 2020. The copyright holder for this preprint (which was not certified by peer review) is the author/funder, who has granted bioRxiv a license to display the preprint in perpetuity. It is made available under aCC-BY-NC-ND 4.0 International license.

\section{Tables}

575

Table 1. PCR primers and conditions used for bacteria identification

\section{7}

\begin{tabular}{|c|c|c|c|c|c|c|c|}
\hline $\begin{array}{l}\text { Organism } \\
\text { Name }\end{array}$ & $\begin{array}{c}\text { Primer } \\
\text { Type }\end{array}$ & Sequence & Start & $\begin{array}{c}\text { Leng } \\
\text { th }\end{array}$ & $\mathbf{T m}$ & GC \% & Amplicon \\
\hline \multirow{6}{*}{ Sulfitobacter } & Forward-1 & TAATACCGCATACGCCCTTC & 120 & 20 & 54.6 & 50.0 & \multirow{2}{*}{880} \\
\hline & Reverse-1 & ATCACGGGCAGTTTCCTTAG & 1000 & 20 & 54.8 & 50.0 & \\
\hline & Forward-2 & AACGCGCAGAACCTTACC & 887 & 18 & 55.7 & 55.6 & \multirow{2}{*}{253} \\
\hline & Reverse-2 & ATTGTAGCACGTGTGTAGCC & 1140 & 20 & 55.2 & 50.0 & \\
\hline & Forward-3 & AGGAAACTGCCCGTGATAAG & 1060 & 20 & 54.8 & 50.0 & \multirow{2}{*}{960} \\
\hline & Reverse-3 & GGCTACCTTGTTACGACTTCA & 1400 & 21 & 54.4 & 47.6 & \\
\hline \multirow{6}{*}{$\begin{array}{l}\text { Pseudo- } \\
\text { altermonas }\end{array}$} & Forward-1 & GTCATGAATCACTCCGTGGTAA & 30 & 22 & 54.6 & 45.5 & \multirow{2}{*}{808} \\
\hline & Reverse-1 & GAGTGTGATAGAGGGTGGTAGA & 838 & 22 & 55.0 & 50.0 & \\
\hline & Forward-2 & CTCTGTATGTCAAGTGTAGGTAAGG & 500 & 25 & 54.4 & 44.0 & \multirow{2}{*}{770} \\
\hline & Reverse-2 & ATTGGCCCAAGTGGGATTAG & 1270 & 20 & 55.0 & 50.0 & \\
\hline & Forward-3 & GTACGCTTTACGCCCAGTAAT & 930 & 21 & 55.0 & 47.6 & \multirow{2}{*}{520} \\
\hline & Reverse-3 & GTCGAGCGGTAACAGAAAGTAG & 1450 & 22 & 55.1 & 50.0 & \\
\hline \multirow{6}{*}{ Cobetia } & Forward-1 & AACTCAGGCTAATACCGCATAC & 150 & 22 & 54.5 & 45.5 & \multirow{2}{*}{530} \\
\hline & Reverse-1 & CTGGTATTCCTCCCGATCTCTA & 700 & 22 & 54.9 & 50.0 & \\
\hline & Forward-2 & GGAAGAACGCTTCGGGATTA & 398 & 20 & 54.7 & 50.0 & 707 \\
\hline & Reverse-2 & CTCCTTAGAGTTCCCGACATTAC & 1100 & 23 & 54.5 & 47.8 & 102 \\
\hline & Forward-3 & CGGAATTACTGGGCGTAAAG & 495 & 20 & 53.5 & 50.0 & 075 \\
\hline & Reverse-3 & CCCTAGGGCTACCTTGTT & 1420 & 18 & 53.6 & 55.6 & \\
\hline \multirow{2}{*}{ Alteromonas } & Forward & TCAACCTGGGATGGTCATTTAG & 589 & 22 & 62.0 & 45.5 & \multirow{2}{*}{765} \\
\hline & Reverse & GGAACGTATTCACCGCAGTAT & 1353 & 21 & 62.0 & 47.6 & \\
\hline \multirow{6}{*}{ Bacillus } & Forward-1 & 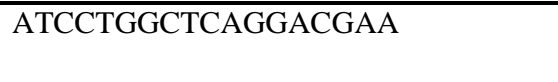 & 16 & 22 & 55.4 & 50.0 & \multirow{2}{*}{706} \\
\hline & Reverse-1 & CCTCCACATCTCTACGCATTTC & 722 & 18 & 55.8 & 55.6 & \\
\hline & Forward-2 & TCGGATCGTAAAGCTCTGTTG & 427 & 21 & 54.7 & 47.6 & \multirow{2}{*}{811} \\
\hline & Reverse-2 & GTGTGTAGCCCAGGTCATAAG & 1238 & 21 & 55.1 & 52.4 & \\
\hline & Forward-3 & GGGAGCGAACAGGATTAGATAC & 781 & 22 & 54.7 & 50.0 & \multirow{2}{*}{739} \\
\hline & Reverse-3 & CGGCTACCTTGTTACGACTT & 1520 & 20 & 54.6 & 50,0 & \\
\hline
\end{tabular}


582 Table 2. List of bacterial isolates which showed a white light fluorescence under UV light when grown on different sugars. The white fluorescence indicates the accumulating of PHA (Oshiki et al., 2011).

585

\begin{tabular}{|c|c|c|c|c|c|c|c|c|c|c|}
\hline \multirow[t]{2}{*}{ Bacteria's no. } & \multirow[t]{2}{*}{ Bacteria genus } & \multicolumn{9}{|c|}{ Sugar type } \\
\hline & & Gal & Mat & Fru & Ara & Mas & Glu & Rha & GA & Xyl \\
\hline 49 & Sulfitobacter & + & & + & & & + & & & + \\
\hline 3 & Bacillus sp. & + & + & + & & & + & & & \\
\hline $25,26,27$ & Uncultured Altermonas & & + & + & & & + & + & & + \\
\hline 28 & Altermonas & & + & + & & & + & + & & + \\
\hline 52,56 & Unclassified vibrio & & + & + & & & + & & & \\
\hline 41 & Vibrio $s p$ & & + & + & & & + & & & \\
\hline 6,37 & Sulfitobacter sp. & & & & & & + & & & + \\
\hline $68,80,81,85$ & Unclassified Microbacteria & + & & + & + & + & + & & & + \\
\hline 86 & Unclassified Microbacteria & + & & + & + & + & + & + & & + \\
\hline $\begin{array}{l}75-76,92,104- \\
105,107\end{array}$ & Cobetia & + & + & + & & & + & & & \\
\hline 13 & Pseudoaltermononas & + & + & + & & + & + & & & \\
\hline 71 & Pseudoaltermononas & + & & + & + & + & + & + & & \\
\hline 14 & Pseudoaltermononas & + & + & + & & & + & & & \\
\hline 65 & Cobetia & + & + & + & & & + & & & \\
\hline 82 & Sulfitobacter sp. & & & & & & + & & & \\
\hline 48 & Sulfitobacter sp. & & & & & & & & & + \\
\hline
\end{tabular}

+ Positive-PHA. Gal-galactose; Mat-mannitol; Fru-fructose; Ara-arabinose; Mas-mannose; Glu-glucose; Rha- 
593

\begin{tabular}{|c|c|c|c|c|c|c|}
\hline Organism Name & $\begin{array}{l}\text { Sugar } \\
\text { Type }\end{array}$ & $\begin{array}{l}\text { DCW } \\
\left(\mathrm{g} \mathrm{L}^{-1}\right)\end{array}$ & $\begin{array}{l}\text { PHA Yield } \\
\quad\left(\mathrm{mg} \mathrm{L}^{-1}\right)\end{array}$ & $\begin{array}{c}\text { PHA Yield } \\
\text { (\%DCW) }\end{array}$ & $\begin{array}{c}\text { SD of } \\
\text { PHA \% }\end{array}$ & $\begin{array}{c}\text { Monomer } \\
\text { Composition } \\
(\mathbf{m o l} \%), 3 \mathrm{HB}\end{array}$ \\
\hline \multirow[t]{2}{*}{ Bacillus isolate no. 3} & Fructose & 1.14 & 114 & 10.03 & 0.76 & 100 \\
\hline & Glucose & 1.96 & 221 & 13.97 & 1.13 & 100 \\
\hline $\begin{array}{l}\text { Sulfitobacter sp. Isolate no. } \\
48\end{array}$ & Mannitol & 2.54 & 196 & 7.73 & 0.98 & 100 \\
\hline \multirow[t]{2}{*}{ Cobetia isolate no. 65} & Mannitol & 6.36 & 125 & 17.11 & 1.41 & 100 \\
\hline & Galactose & 1.06 & 573 & 11.83 & 1.45 & 100 \\
\hline $\begin{array}{l}\text { Pseudoaltermonas isolate } \\
\text { no. } 71\end{array}$ & Fructose & 2.54 & 189 & 7.46 & 0.64 & 100 \\
\hline \multirow[t]{4}{*}{ Cobetia isolate no. 75} & Fructose & 2.08 & 125 & 8.63 & 1.15 & 100 \\
\hline & Galactose & 0.78 & 180 & 16.04 & 1.32 & 100 \\
\hline & Mannitol & 4.72 & 762 & 18.56 & 0.88 & 100 \\
\hline & Glucose & 3.72 & 876 & 20.91 & 0.82 & 100 \\
\hline Cobetia isolate no. 76 & Mannose & 3.68 & 151 & 1.89 & 0.41 & 100 \\
\hline \multirow[t]{3}{*}{ Cobetia isolate no. 92} & Fructose & 3.26 & 206 & 4.45 & 0.92 & 100 \\
\hline & Mannitol & 4.50 & 251 & 8.91 & 0.51 & 100 \\
\hline & Galactose & 1.88 & 355 & 7.69 & 1.35 & 100 \\
\hline \multirow[t]{4}{*}{ Cobetia isolate no. 104} & Galactose & 1.02 & 111 & 10.87 & 1.34 & 100 \\
\hline & Mannitol & 1.02 & 116 & 11.34 & 0.75 & 100 \\
\hline & Glucose & 0.82 & 131 & 16.01 & 1.12 & 100 \\
\hline & Fructose & 4.44 & 718 & 23.29 & 0.57 & 100 \\
\hline Cobetia isolate no. 105 & Mannitol & 4.58 & 574 & 61.00 & 1.23 & 100 \\
\hline \multirow[t]{2}{*}{ Cobetia isolate no. 107} & Glucose & 2.03 & 231 & 11.37 & 0.95 & 100 \\
\hline & Fructose & 3.53 & 968 & 27.45 & 0.84 & 100 \\
\hline
\end{tabular}

Table 3. Microbial production of PHA from different supplemented sugars. A total of 10 bacteria were analyzed on different sugars for PHA production. The best bacteria with the highest PHA production were listed in the table below. DCW represents "Dry Cell Weight". SD represents "Standard Deviation". 
Table 4. Microbial production of $\mathrm{P}(3 \mathrm{HB})$ using mixed culture and mixed sugars. A Comparison between pure and mixed bacteria cultures from Cobetia and Bacillus genus are grown on single and mixture sugars substrates. DCW represents "dry cell weight", and $\mathrm{P}(3 \mathrm{HB})$ presents poly-3-

600 601 hydroxybutyrate. Cobetia presented as Cob. and Bacillus presents as Bac.

\begin{tabular}{lllll}
\hline \multicolumn{1}{c}{$\begin{array}{c}\text { Bacteria/ bacterial } \\
\text { mixture }\end{array}$} & \multicolumn{1}{c}{$\begin{array}{c}\text { Sugar/sugar } \\
\text { mixture }\end{array}$} & $\begin{array}{c}\text { DCW } \\
\left(\mathbf{m g ~ L}^{-1}\right)\end{array}$ & $\begin{array}{c}\text { P(3HB) in } \\
\text { DCW (\%) }\end{array}$ & $\begin{array}{c}\text { SD of } \\
\text { PHA \% }\end{array}$ \\
\hline Cob. 75, Cob. 107 & Glucose & 97 & 1.45 & 1.12 \\
Cob. 104, Cob. 107 & Fructose & 98 & 10.05 & 0.87 \\
$\begin{array}{l}\text { Bac. 3, Cob. 75 Cob. 107 } \\
\text { Cob. 65, Cob. 75, Cob. }\end{array}$ & Glucose & 62 & 2.27 & 0.91 \\
105 & Mannitol & 39 & 11.61 & 1.24 \\
$\begin{array}{l}\text { Cob. 65, Cob. 75, Cob. } \\
\text { 92 Galactose }\end{array}$ & 32 & 5.15 & 1.56 \\
$\begin{array}{l}\text { Cob. 92, Cob. 104. Cob. } \\
107\end{array}$ & Fructose & 45 & 0.70 & 0.76 \\
\hline
\end{tabular}

602

603 Table 5. Analysis of sugars obtained by acid hydrolysis of Ulva sp.

\begin{tabular}{ccccccc}
\hline $\begin{array}{c}\text { Glucose } \\
\mathbf{~ m g} / \mathbf{g}\end{array}$ & $\begin{array}{c}\text { Rhamnose } \\
\mathbf{m g} / \mathbf{g}\end{array}$ & $\begin{array}{c}\text { Galactose } \\
\mathbf{~ m g / g}\end{array}$ & $\begin{array}{c}\text { Xylose } \\
\mathbf{m g} / \mathbf{g}\end{array}$ & $\begin{array}{c}\text { Fructose } \\
\mathbf{m g} / \mathbf{g}\end{array}$ & $\begin{array}{c}\text { Glu acid } \\
\mathbf{m g} / \mathbf{g}\end{array}$ & $\begin{array}{c}\text { Total } \\
\mathbf{m g} / \mathbf{g}\end{array}$ \\
\hline $16.1 \pm 0.8$ & $6.2 \pm 0.45$ & $1.0 \pm 0.11$ & $1.6 \pm 0.22$ & $2.8 \pm 0.41$ & $1.3 \pm 0.11$ & $27.1 \pm 1.83$ \\
\hline
\end{tabular}

604

605

606

607 


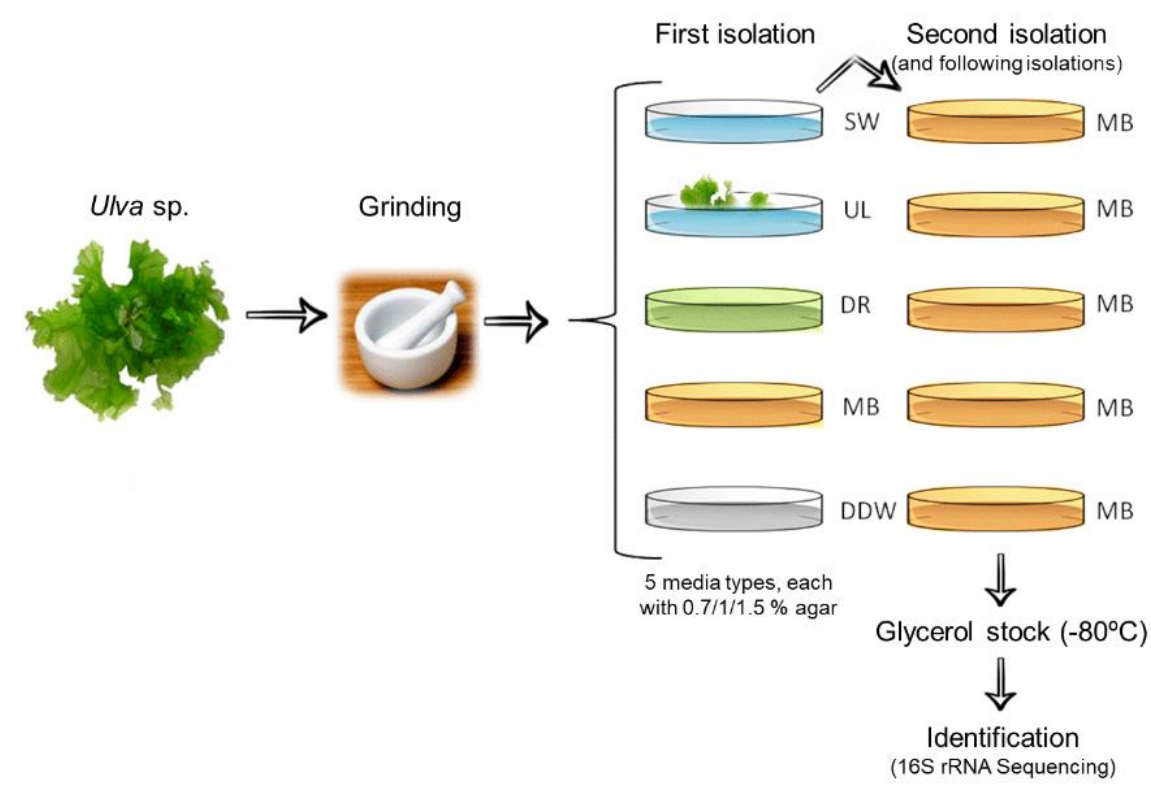

612 Figure 1. Illustration of the bacterial isolation from Ulva sp. The Ulva associated bacteria were isolated after Ulva sp. was ground and streaked on different plates. The isolated bacteria were stored and genetically identified. 

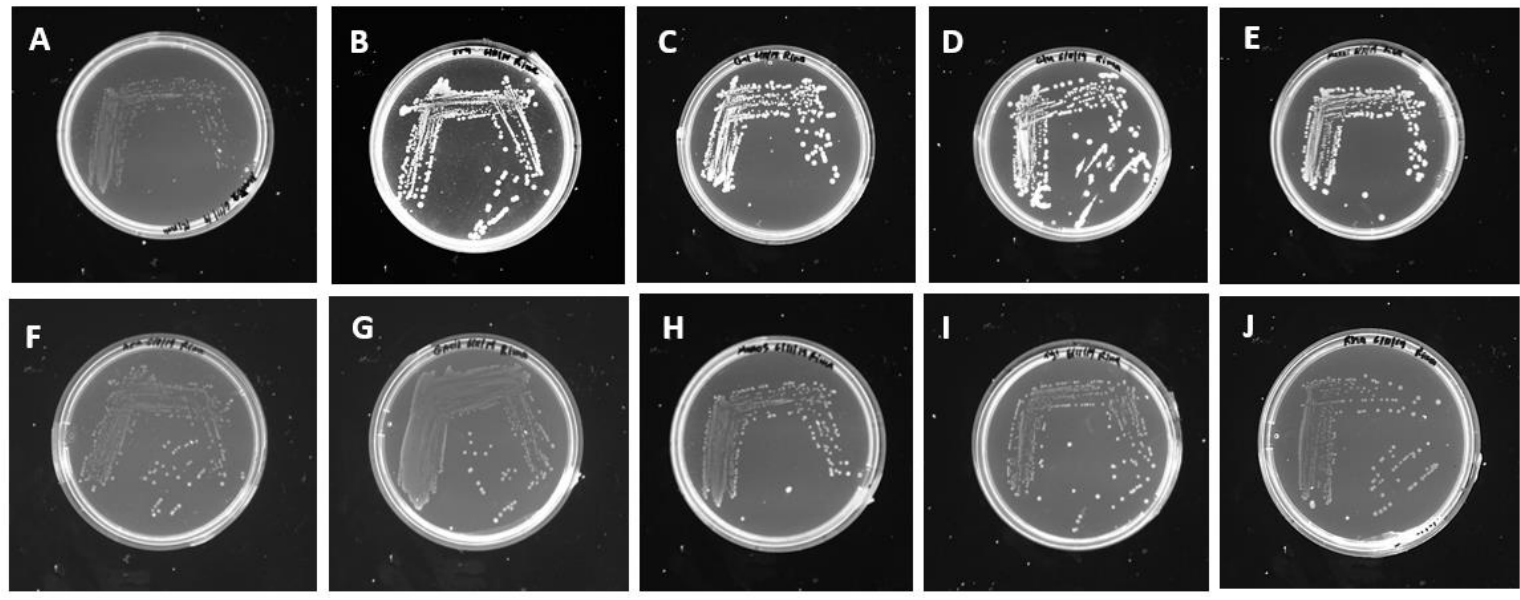

Figure 2. Screening of Cobetia (no. 104) for PHA production on different sugars under UV light: Anegative control, B-fructose, C-galactose, D-glucose, E-mannitol, F-arabinose, G-glucuronic acid, $\mathbf{H}$-mannose, I-xylose, J-rhamnose. Fluorescence indicates the presence of PHA accumulation inside the bacterial cells. Cobetia (no. 104) utilize mannitol, fructose, galactose and glucose for PHA production while no PHA is observed on other sugars.

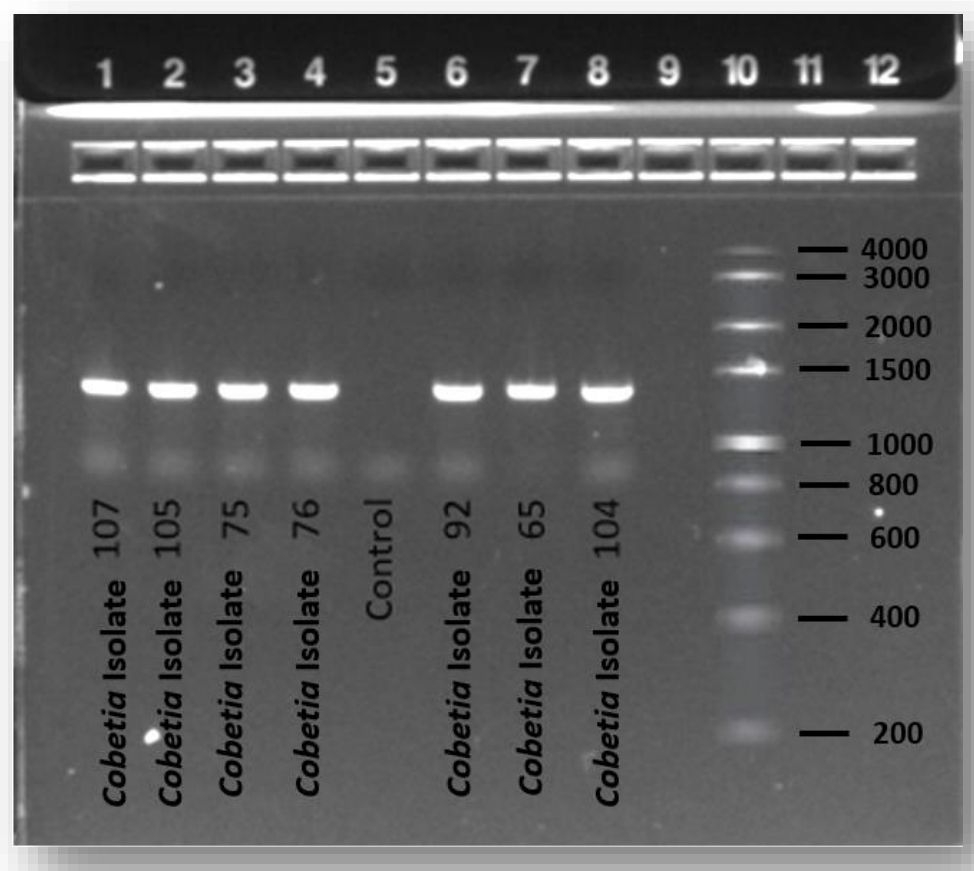

630 Figure 3. Agarose gel electrophoresis represents the amplicon of 16S rRNA gene of strains isolated 631 from seaweeds associated bacteria. 
bioRxiv preprint doi: https://doi.org/10.1101/2020.12.05.413369; this version posted December 6, 2020. The copyright holder for this preprint (which was not certified by peer review) is the author/funder, who has granted bioRxiv a license to display the preprint in perpetuity. It is made available under aCC-BY-NC-ND 4.0 International license.

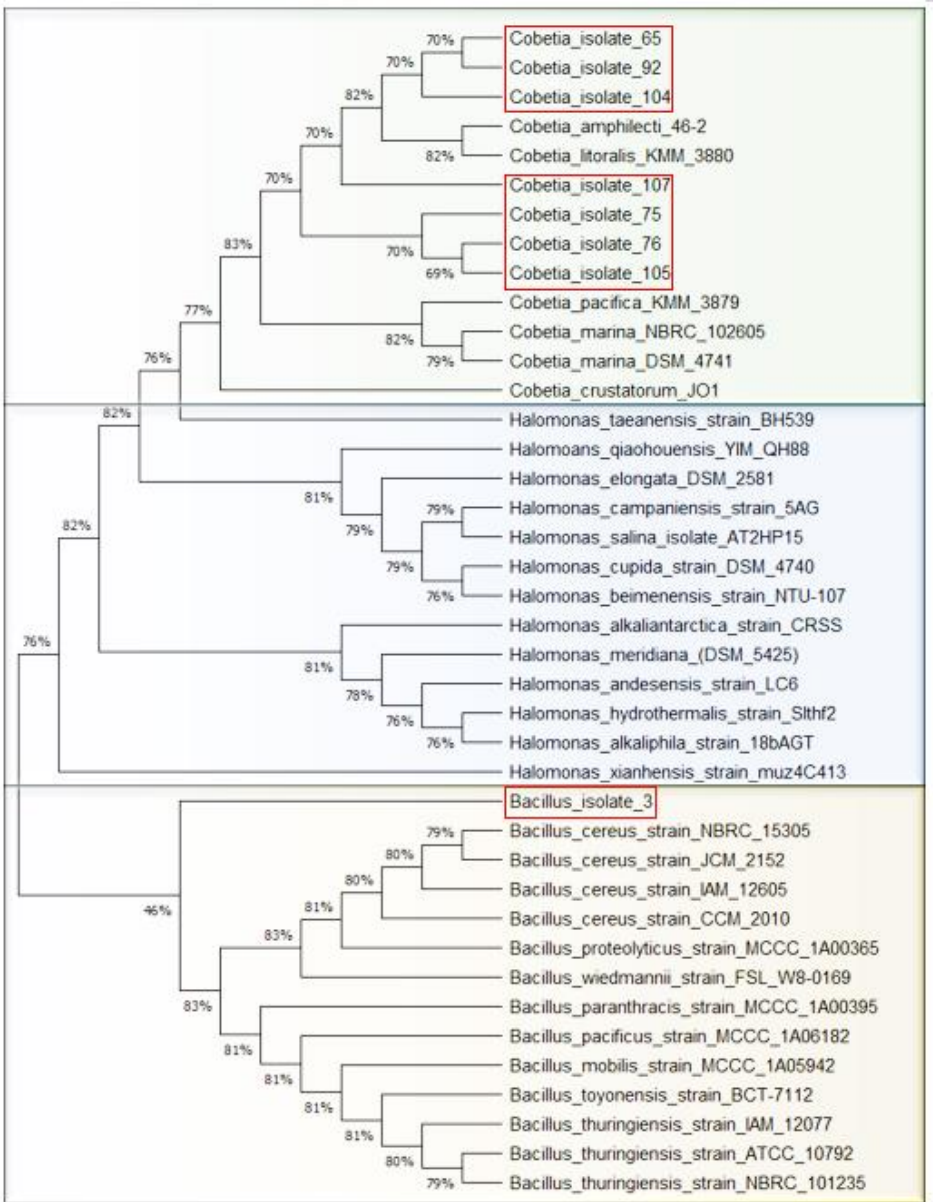

Figure 4. Phylogenetic relationships among the isolates drawn by MEGA 5 with 100 resamplings. The bacteria in bold were isolated in the current study. 


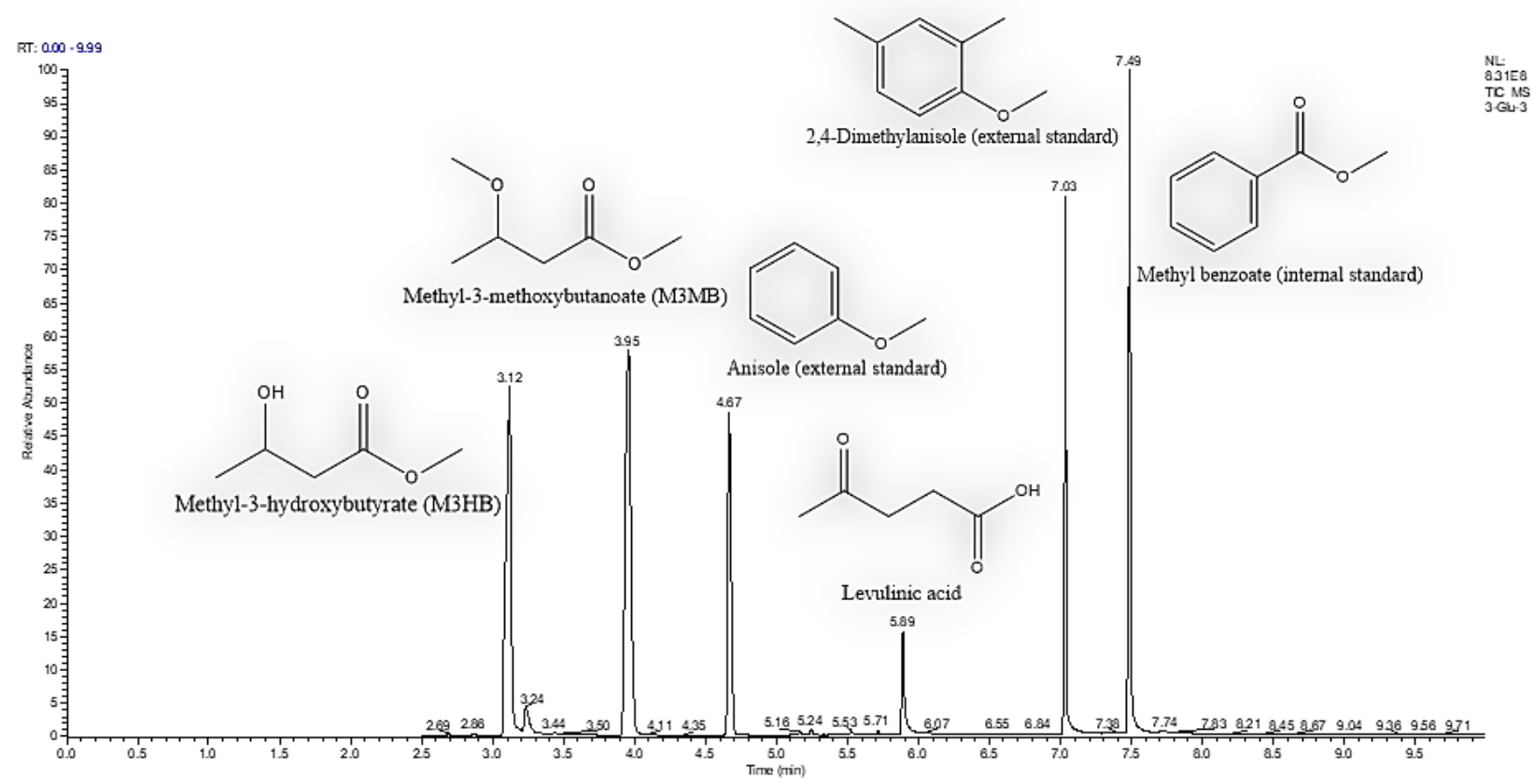

Figure 5. GC-MS chromatogram of methylated derivatives of 3HB (M3HB and M3MB), levulinic acid and three standards (anisole, methyl benzoate and 2,4-dimethyl anisole). 


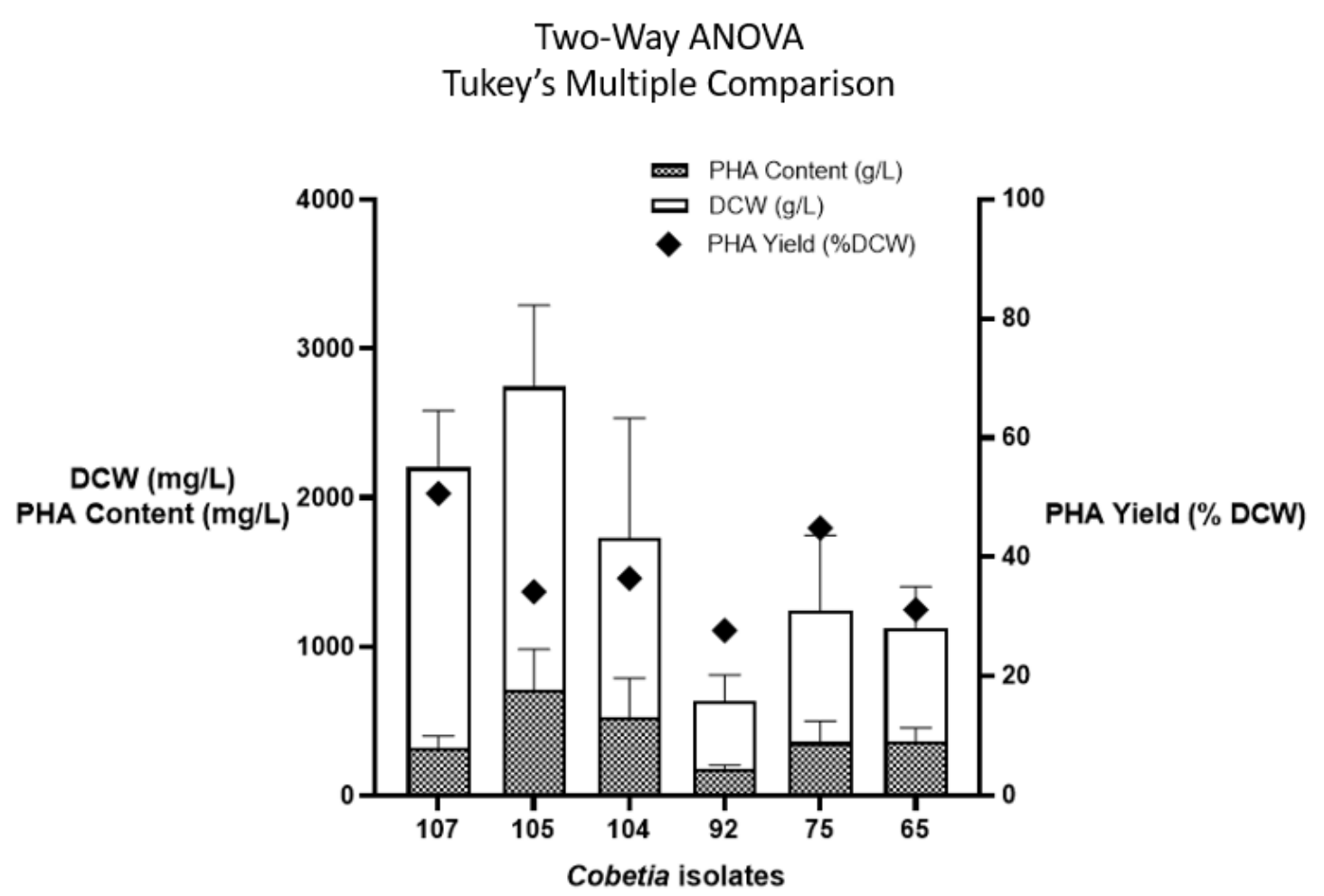

679 Figure 6. $\mathrm{P}(3 \mathrm{HB})$ content, $\mathrm{P}(3 \mathrm{HB})$ yield and DCW of six Cobetia strains (Cobetia isolate no. 107, 680 Cobetia isolate no. 105, Cobetia isolate no. 104, Cobetia isolate no. 92, Cobetia isolate no. 75, and Cobetia isolate no. 65 grown on a mixture carbon source, i.e. glucose, fructose and mannitol. Five replicates were obtained. Two-Way ANOVA, Tukey's multiple comparison test was performed. 


\section{One-Way ANOVA \\ Holm-Sidak's multiple comparisons test}

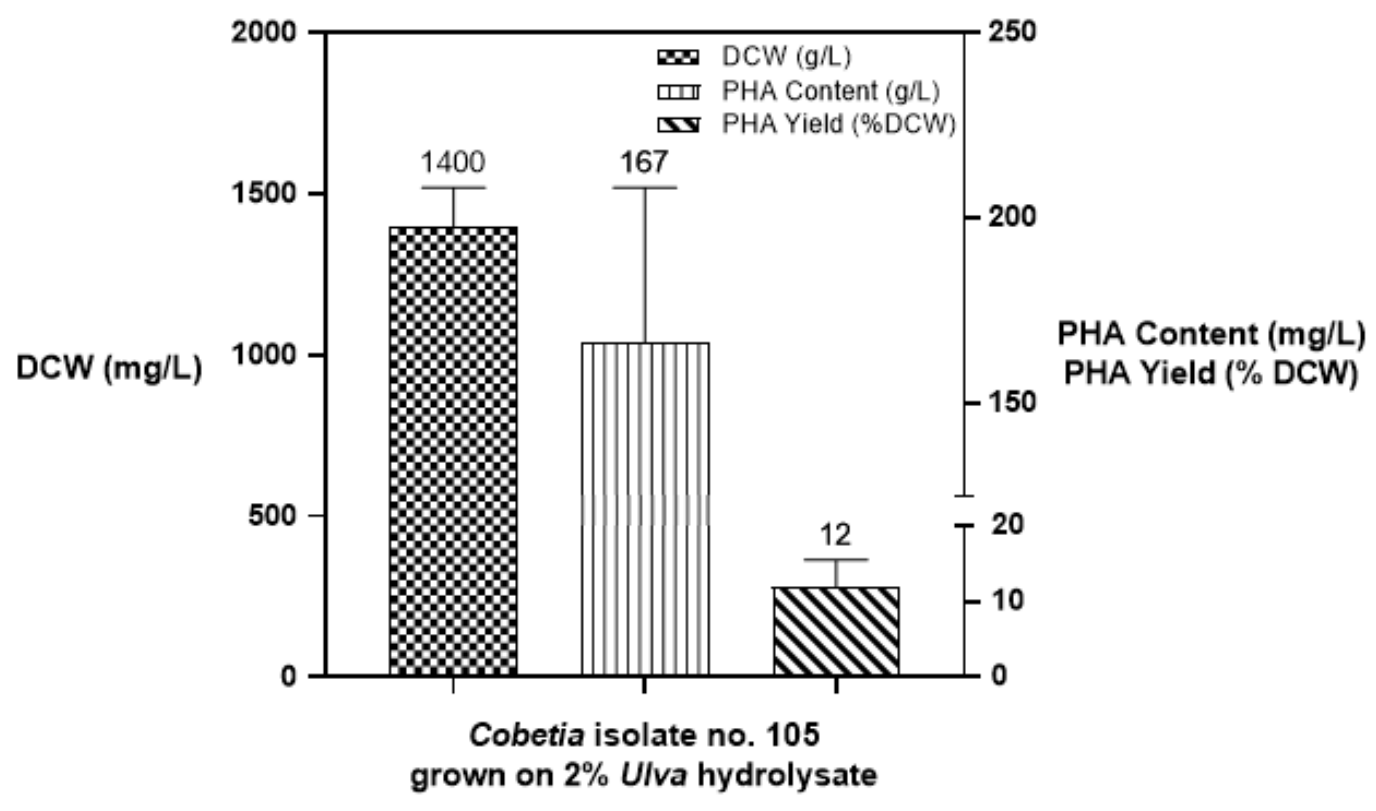

684

685

686

687

688

689

690

691

692

693

694

695

\author{
"DCW (g/L) vs. PHA Content (g/L)" \\ "DCW (g/L) vs. PHA Yield (\%DCW)" \\ $* * * * p<0.0001$ \\ "PHA Content (g/L) vs. PHA Yield (\%DCW)" $\quad * p<0.04$
}

Figure 7. PHA content, PHA yield and DCW of Cobetia isolate no. 105 grown on Ulva sp. hydrolysate as a sole carbon. One-Way ANOVA, Holm Sidak's multiple comparison test was performed. 


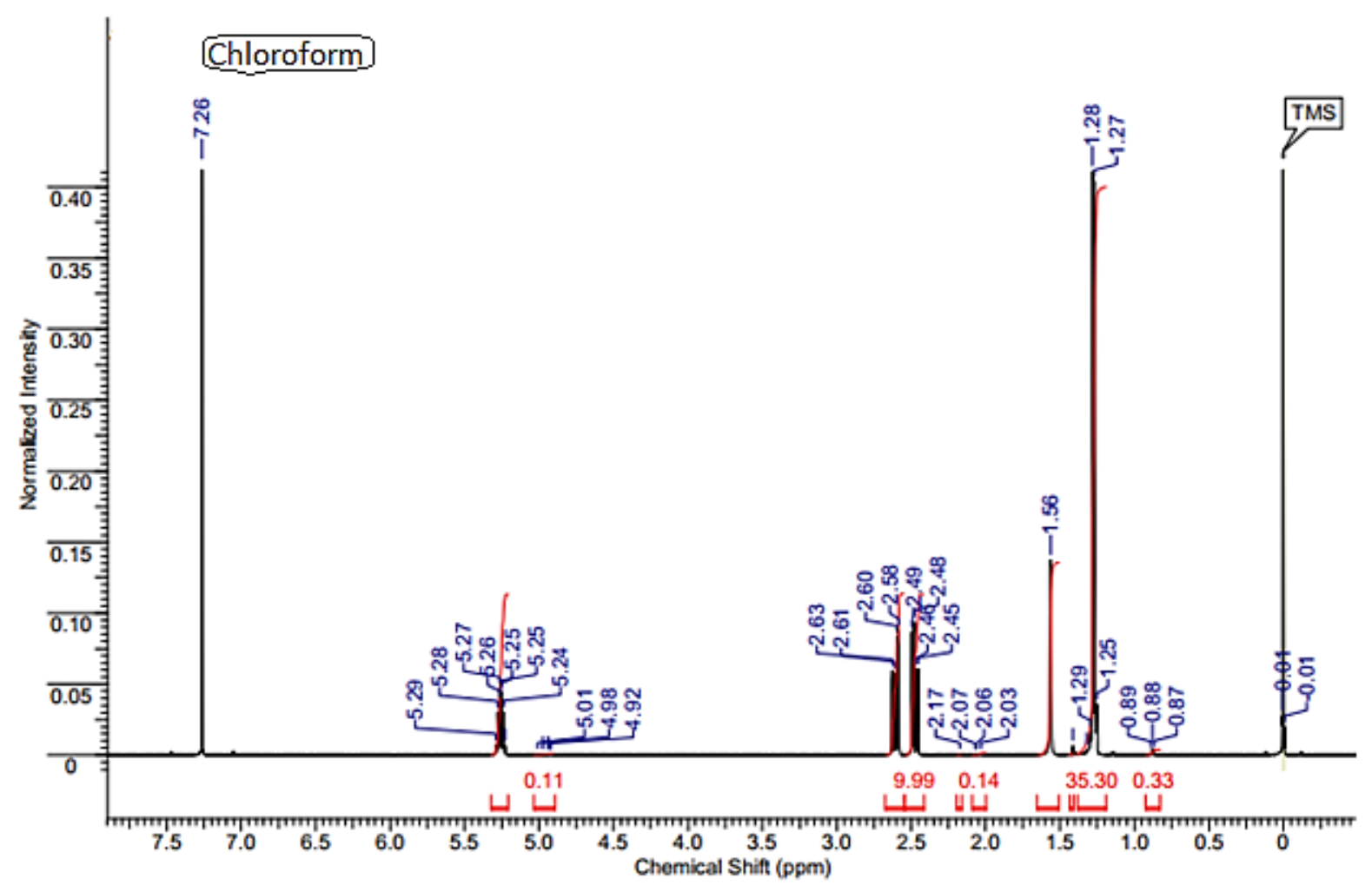

697

698 Figure 8. ${ }^{1} \mathrm{H}$ NMR spectrum of the $\mathrm{P}(3 \mathrm{HBV})$ produced by Cobetia isolate no. 105 when grown on 699 sugar mixture, i.e. glucose, fructose and mannitol and extracted with chloroform.

700

701

702

703

704

705 


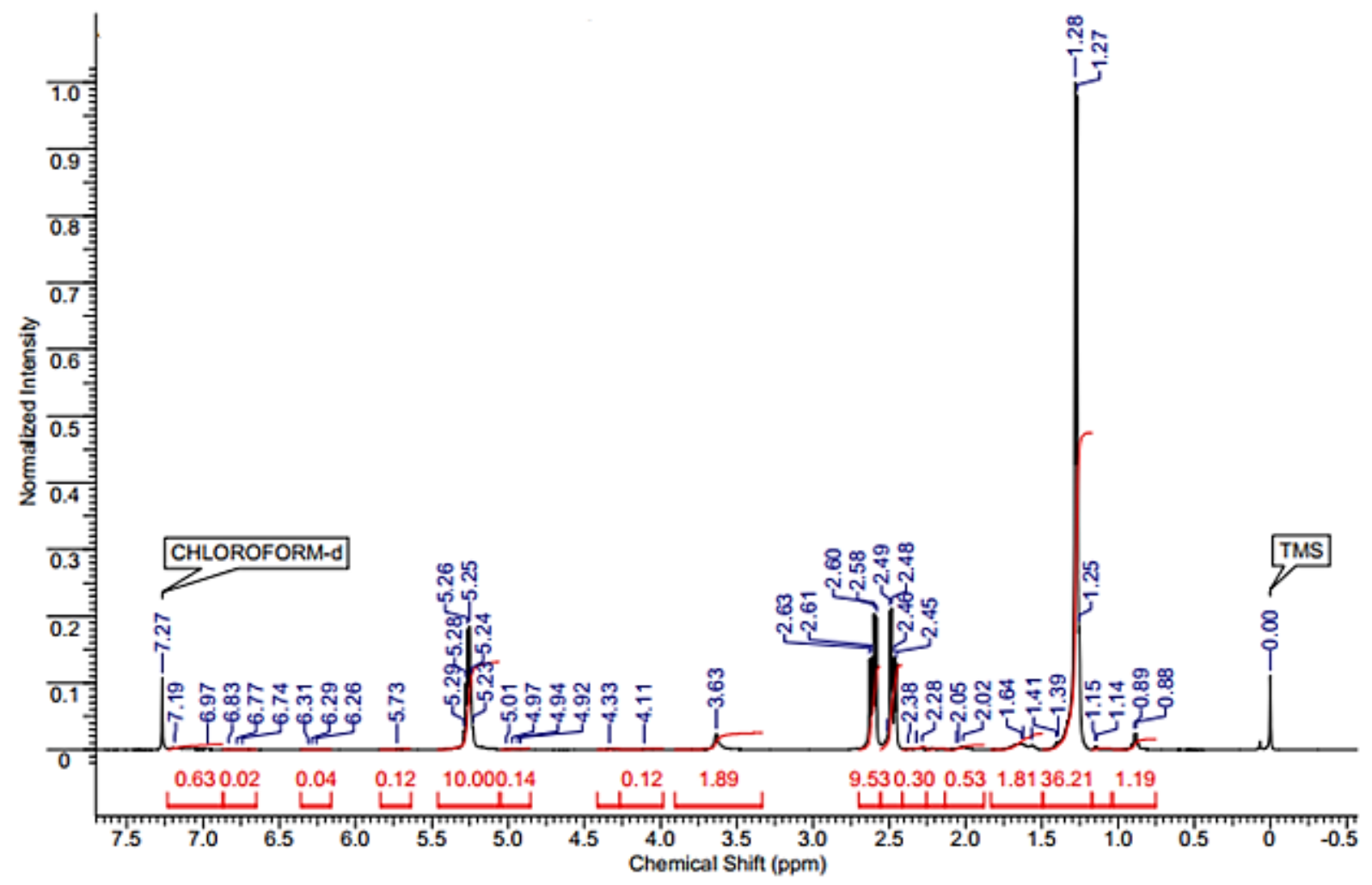

708 Figure 9. ${ }^{1} \mathrm{H}$ NMR spectrum of the $\mathrm{P}((3 \mathrm{HBV})$ produced by Cobetia isolate no. 105 when grown on 709 Ulva sp. hydrolysate and extracted with chloroform. 